\title{
Spina Bifida Occulta in an Adult Presenting as Perilesional Hemorrhage
}

\author{
Amit Agrawal $^{1} \quad$ Vissa Santhi $^{2} \quad$ Ranjan Kumar Jena $^{1} \quad{\text { Umamaheswara Reddy } V^{3}}^{3}$ Yashwant Sandeep $^{1}$ \\ 1 Department of Neurosurgery, Narayana Medical College Hospital, \\ Chinthareddypalem, Nellore, Andhra Pradesh, India \\ 2 Department of Pathology, Narayana Medical College Hospital, \\ Chinthareddypalem, Nellore, Andhra Pradesh, India \\ ${ }^{3}$ Department of Radiology, Narayana Medical College Hospital, \\ Address for correspondence Dr. Amit Agrawal, MCh, Department of \\ Neurosurgery, Narayana Medical College Hospital, \\ Chinthareddypalem, Nellore, Andhra Pradesh 524003, India \\ (e-mail: dramitagrawal@gmail.com).
} Chinthareddypalem, Nellore, Andhra Pradesh, India

Indian J Neurosurg 2017;6:79-81.

\begin{abstract}
Keywords

- spina bifida occulta

- spinal dysraphism

- lipoma

- intraspinal lipoma

Occult spinal dysraphism with spinal lipoma, is a rare congenital spinal dysraphic anomaly which usually involves lumbosacral region and manifests in childhood. In the present article, we discuss a case of a 26-year-old man who developed sudden low back pain following intercourse. Magnetic resonance imaging of the lumbosacral spine was suggestive of spina bifida occulta with hemorrhage. The patient underwent a L4-5 laminectomy in the emergency. There was the presence of altered blood in the vicinity of the lesion suggestive of recent hemorrhage. Histopathological examination of the lesion was suggestive of the lipoma. In the present case, the patient had occult spina bifida due to lumbosacral lipoma leading to the tethering of the dura. Strenuous activity resulted in overstretching of the tethered structures and subsequent hemorrhage and intense low back pain which responded well to the surgical treatment.
\end{abstract}

\section{Introduction}

Occult spinal dysraphism with spinal lipoma, is a rare congenital spinal dysraphic anomaly which usually involves lumbosacral region and manifests in childhood. ${ }^{1-3}$ These lesions can be present clinically due to the mass effect leading to the compression of the neural structures or due to the tethering of the cord. ${ }^{3-5}$ In the present article, we discuss a case of a young adult patient who had had spinal bifida occulta and developed sudden low back pain following intercourse.

\section{Case Report}

A 26-year-old man presented with sudden onset of low back radiating to both the lower limbs of 1-day duration. He was recently married and the pain precipitated during intercourse. There was no history of fever, trauma, or similar episodes of pain in the past. There was no history of focal weakness or bowel and bladder disturbances. His general and systemic examination was normal. Higher mental functions, cranial nerves, motor and sensory examinations were normal. All the deep tendon reflexes were normal. Planters were bilateral flexor. There was no neck rigidity; however Kerning sign was positive. Spine examination revealed local tenderness over lumbosacral (L4-5) spinal region. There were no deformities or gibbous. Magnetic resonance imaging (MRI) of the lumbosacral spine axial T2-weighted images showed spina bifida of L4 and paraspinal muscle soft tissue hyperintensities; sagittal images showed displacement of the dura and cauda equina anteriorly by $\mathrm{T} 2$ hyperintense collection. The L4/L5 interspinous ligament is showing hyperintensities (- Fig. 1). The findings were suggestive of spina bifida occulta, lipoma associated with hemorrhage. The patient underwent a L4-5 laminectomy in the emergency. There was a partly absent spinous process of L4 vertebral body and it received

June 15, 2016

accepted

June 21, 2016

published online

September 29, 2016
DOI http://dx.doi.org/

10.1055/s-0036-1588040. ISSN 2277-954X. (c) 2017 Neurological Surgeons' Society
of India

License terms

(c) $9 \ominus \$$ 


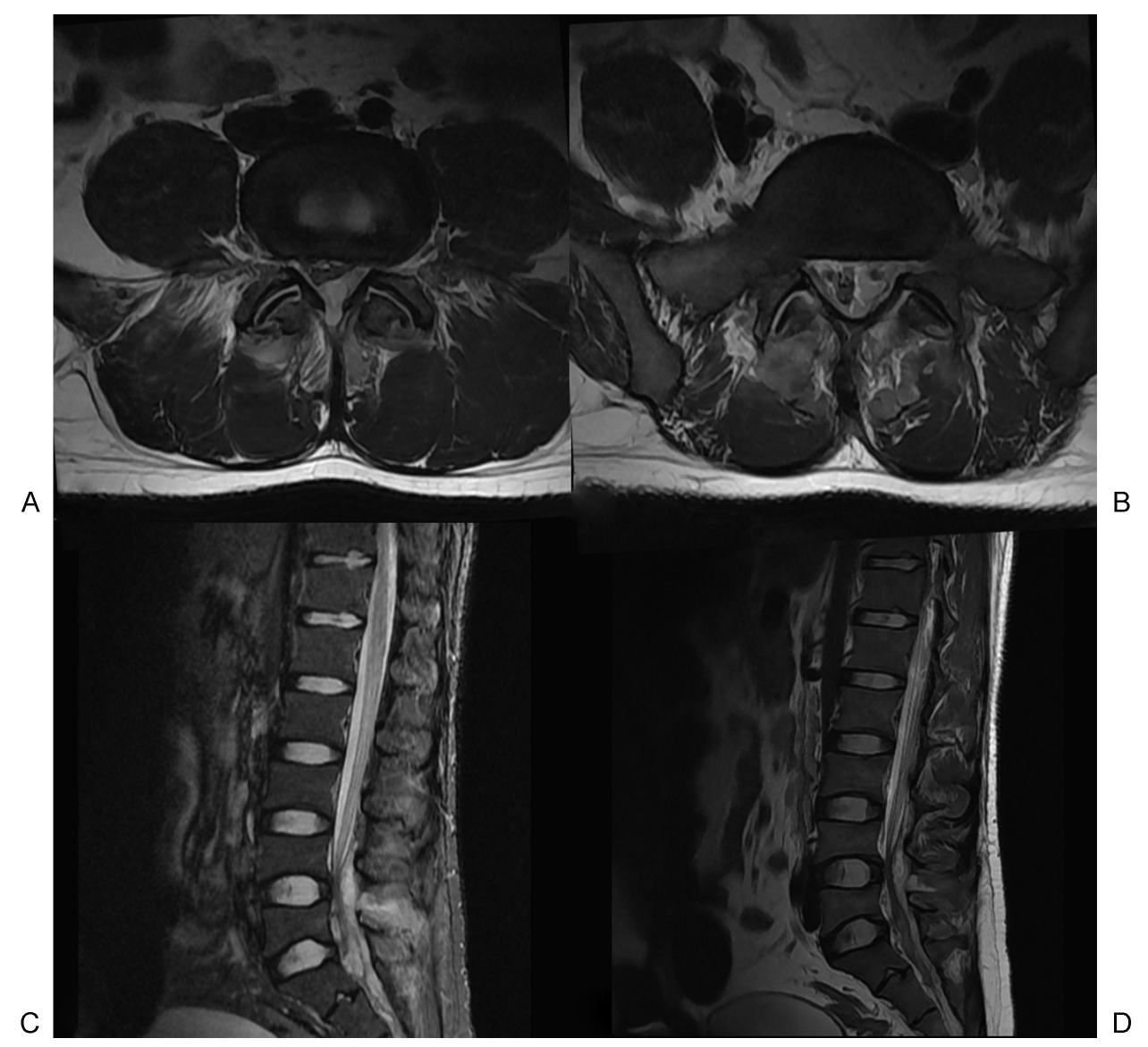

Fig. 1 Axial T2-weighted images (A, B) showing spina bifida of L4 and paraspinal muscle soft tissue hyperintensities, sagittal images (C, D) showing displacement of the dura and cauda equina anteriorly by $T 2$ hyperintense collection. The $L 4 / L 5$ interspinous ligament is showing hyperintensities.

was replaced by the fatty tissue. The dura was attached to the spinous process and fatty tissue suggestive of tethering. There was the presence of altered blood in the vicinity of lesion suggestive of recent hemorrhage. The dura was detethered and it became lax and pulsatile. Histopathological examination of the lesion showed lobules of mature adipocytes with eccentrically placed nuclei separated by fibrovascular septa which were containing congested blood vessels suggestive of the lipoma
(-Fig. 2). The patient recovered well after surgery and is doing well at follow-up.

\section{Discussion}

The spina bifida occulta can be associated with local cutaneous markers (i.e., midline hypertrichosis, cutaneous hemangiomas, dermal sinus, and midline subcutaneous lipoma). ${ }^{1,6}$ If the lesion

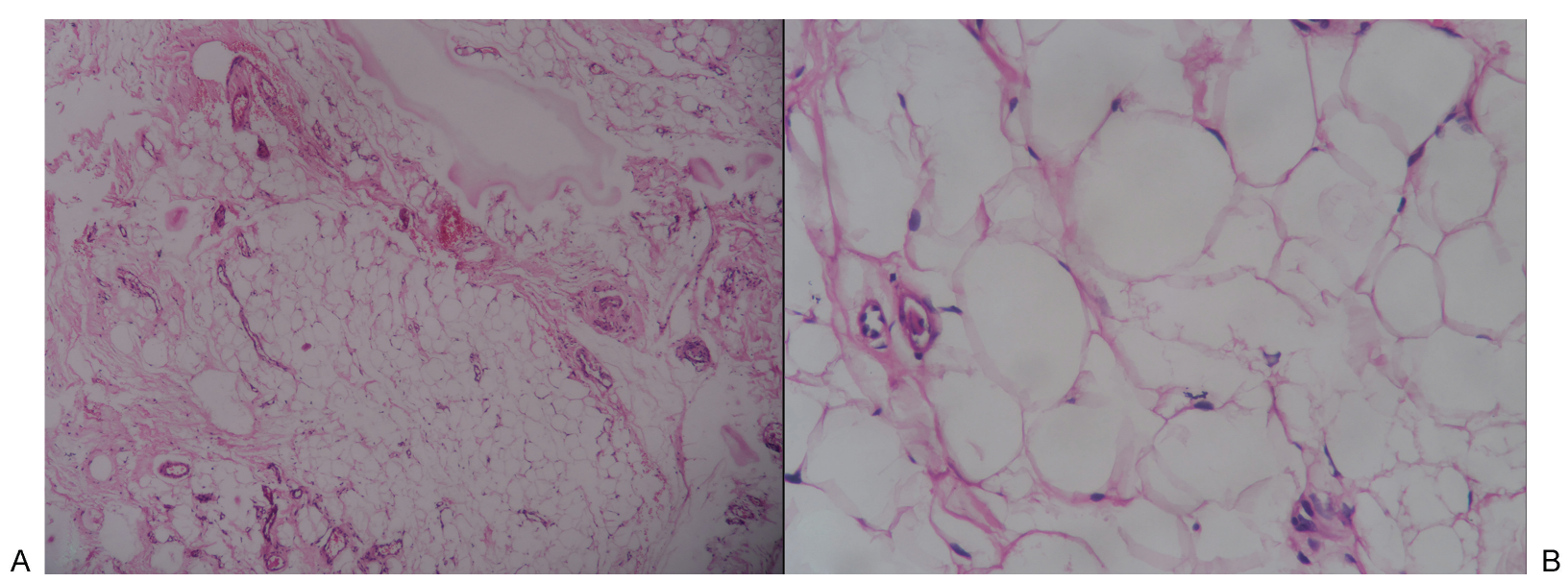

Fig. 2 (A) Lobules of mature adipocytes separated by fibrovascular septa containing congested blood vessels $(H \& E, \times 100)$ and $(B)$ mature adipocytes with eccentrically placed nuclei $(H \& E, \times 400)$. H\&E, hematoxylin and eosin stain. 
causes tethering or mass effect than the patients can present with local and radicular pain, hyporeflexia, spasticity, sensory disturbances, motor weakness, and bowel/bladder dysfunction. ${ }^{1,7}$ Adult patients usually present with low back pain (in contrast to children) and if the lesion is long-standing and progressive in nature than neurological abnormalities including motor weakness, sensory disturbances, abnormal reflexes, and bowel/bladder dysfunction may develop. ${ }^{3,8,9}$ Plain radiographs, computed tomography scan (with bone window), and MRI of appropriate regions have been used in conjunction with each other to make a diagnosis (including details of the lesions and associated anomalies) of spina bifida occulta and to decide the management strategy. ${ }^{1,10-12}$ MRI is the imaging modality of choice and lipomatous tissue appears hyperintense on T1-weighted MR images and hypointense on T2-weighted MR images. ${ }^{10,13}$ Congenital lumbosacral lipomas, which lead to mass effect, neurological symptoms, and/or cosmetic deformity need surgical intervention. ${ }^{1}$ The surgical intervention is aimed at to stabilize the neurological functions and untethering of the spinal cord (to prevent delayed neurological deterioration). ${ }^{1,3,14-16}$

\section{Conclusion}

In the present case, the patient had occult spina bifida due to lumbosacral lipoma leading to the tethering of the dura. Strenuous activity resulted in overstretching of the tethered structures and subsequent hemorrhage and intense low back pain which responded well to surgical treatment.

\section{References}

1 Brkić H, Altumbabić H, Moranjkić M. Lipoma and occult spinal dysraphism. Acta Med Acad 2006;35:107-112
2 James CC, Lassman LP. Diastematomyelia and the tight filum terminale. J Neurol Sci 1970;10(2):193-196

3 McLone DG. Occult Dysraphism and the Tethered Spinal Cord Lipomas. Pediatric Neurosurgery. Philadelphia, PA: Churchill Livingstone; 1999:61-78

4 Kanev PM, Bierbrauer KS. Reflections on the natural history of lipomyelomeningocele. Pediatr Neurosurg 1995;22(3):137-140

5 Soonawala N, Overweg-Plandsoen WC, Brouwer OF. Early clinical signs and symptoms in occult spinal dysraphism: a retrospective case study of 47 patients. Clin Neurol Neurosurg 1999;101(1):11-14

6 James CC, Lassman LP. Spinal dysraphism. Spinal cord lesions associated with spina bifida occulta. Physiotherapy 1962;48:154-157

7 Schropp C, Speer CP, Schweitzer T, Krauss J. Congenital skin lesions in occult spinal dysraphism-what is typical? [in German]. Z Geburtshilfe Neonatol 2006;210(6):222-227

8 Warder DE, Oakes WJ. Tethered cord syndrome: the low-lying and normally positioned conus. Neurosurgery 1994;34(4): 597-600, discussion 600

9 Hirsch JF, Pierre-Kahn A. Lumbosacral lipomas with spina bifida. Childs Nerv Syst 1988;4(6):354-360

10 Raghavan N, Barkovich AJ, Edwards M, Norman D. MR imaging in the tethered spinal cord syndrome. AJR Am J Roentgenol 1989; 152(4):843-852

11 Smoker WR, Godersky JC, Knutzon RK, Keyes WD, Norman D, Bergman W. The role of MR imaging in evaluating metastatic spinal disease. AJR Am J Roentgenol 1987;149(6):1241-1248

12 Masaryk TJ, Modic MT, Geisinger MA, et al. Cervical myelopathy: a comparison of magnetic resonance and myelography. J Comput Assist Tomogr 1986;10(2):184-194

13 Patwardhan V, Patanakar T, Patkar D, Armao D, Mukherji SK. MR imaging findings of intramedullary lipomas. AJR Am J Roentgenol 2000;174(6):1792-1793

14 Pierre-Kahn A, Zerah M, Renier D, et al. Congenital lumbosacral lipomas. Childs Nerv Syst 1997;13(6):298-334, discussion 335

15 Kanev PM, Lemire RJ, Loeser JD, Berger MS. Management and longterm follow-up review of children with lipomyelomeningocele, 1952-1987. J Neurosurg 1990;73(1):48-52

16 Byrne RW, Hayes EA, George TM, McLone DG. Operative resection of 100 spinal lipomas in infants less than 1 year of age. Pediatr Neurosurg 1995;23(4):182-186, discussion 186-187 